\title{
FIRST RECORD OF Cephalobaena tetrapoda (PENTASTOMIDA: CEPHALOBAENIDAE) AS A PARASITE ON Liophis lineatus (OPHIDIA: COLUBRIDAE) IN NORTHEAST BRAZIL
}

\author{
ALMEIDA, W. O. ${ }^{1}$, BRITO, S. V. ${ }^{1}$, FERREIRA, F. S. ${ }^{1}$ and CHRISTOFFERSEN, M. L. ${ }^{2}$ \\ ${ }^{1}$ Universidade Regional do Cariri, Departamento de Ciências Físicas e Biológicas, R. Cel. Antônio Luiz, 1161, \\ CEP 63100-000, Crato, CE, Brazil \\ ${ }^{2}$ Universidade Federal da Paraíba, CCEN, Departamento de Sistemática e Ecologia, João Pessoa, PB, Brazil \\ Correspondence to: Waltécio de Oliveira Almeida, Universidade Regional do Cariri, Departamento de Ciências \\ Físicas e Biológicas, R. Cel. Antônio Luiz, 1161, CEP 63100-000, Crato, CE, Brazil, e-mail: walmeida@urca.br \\ Received November 26, 2004 - Accepted March 2, 2005 - Distributed May 31, 2006
}

(With 1 figure)

\begin{abstract}
Cephalobaenidae constitutes one of the main pentastomid groups infecting the respiratory tract of snakes. Six specimens of Liophis lineatus, a colubrid, were collected by active capture and pitfalls installed on the banks of the Batateiras river, close to its source, in the 'APA - Área de Proteção Ambiental' (a protected environmental area of the 'IBAMA - Brazilian Institute for the Environment and Natural Resources'), and in a remnant of the humid tropical forest 'FLONA - Floresta Nacional do Araripe', both in the municipality of Crato, state of Ceará, Northeast Brazil. Out of the six specimens of L. lineatus examined, only one had its lung infected by the pentastomid Cephalobaena tetrapoda. This represents the first record of $C$. tetrapoda as a parasite of a snake in Northeast Brazil, as well as the first record of a colubrid, L. lineatus, as a new host for the pentastomid in Brazil.
\end{abstract}

Keywords: pentastomida, parasitism, snakes, neotropical region.

\section{RESUMO}

\section{Primeira ocorrência de Cephalobaena tetrapoda (Pentastomida: Cephalobaenidae) no Nordeste brasileiro parasitando pulmões de um novo hospedeiro Liophis lineatus (Ophidia: Colubridae)}

Os Cephalobaenidae constituem um dos principais grupos de pentastomídeos que parasitam o trato respiratório de serpentes. Foram coletados seis espécimes de Liophis lineatus pela utilização de coleta ativa e pitfalls instalados às margens da nascente do rio Batateiras, próximo à nascente, 'APA - Área de Proteção Ambiental' (um ambiente protegido pelo 'IBAMA - Instituto Brasileiro do Meio Ambiente e dos Recursos Renováveis'), e em um remanescente de floresta úmida, "FLONA - Floresta Nacional do Araripe". Os dois pontos de coleta estão localizados no município de Crato, Estado do Ceará. Dos seis espécimes de L. lineatus examinados apenas um estava infectado por Cephalobaena tetrapoda em seu pulmão. Isso representa o primeiro registro de C. tetrapoda parasitando uma cobra no Nordeste brasileiro, assim como é o primeiro registro de um colubridae servindo de hospedeiro para C. tetrapoda no Brasil.

Palavras-chave: pentastomida, parasitismo, cobras, região neotropical.

\section{INTRODUCTION}

The family Cephalobaenidae is a group of endoparasites that infect the respiratory tract of snakes. They are characterized by a cephalotorax with five short protuberances, from which the name pentastomid derives. The fifth protuberance is an anterior snout like projection (rostrum) bearing the circular chitinous cadre in the mouth and four leg like projections, located at each side of the body and bearing hooks for clinging to the host (Rego, 1983; Riley, 1986). A cladistic analysis of pentastomids performed by Almeida \& Christoffersen, (1999) 
pointed out the cephalobenids as the most basal group among the recent Pentastomida.

Only three species of Cephalobaena have been described from South America: C. tetrapoda Heymons, 1922, C. giglioli (Hett, 1924) and C. freitasi (Motta \& Gomes, 1968) (Rego, 1983). However, in posterior taxonomic reviews, Ali et al. (1984a, b; 1985) demonstrated that C. giglioli and C. freitasi actually belong to genus Raillietiella. Thus, today Cephalobaenidae is a family of pentastomids constituted by a single neotropical species, $C$. tetrapoda (see Riley, 1986: 61-63). This species live in viperid snakes collected in the neotropical regions, as in Brazil, Paraguay, Uruguay, and Argentina (Sambon, 1922a). In Brazil a single case of $C$. tetrapoda infecting snake was reported in Crotalus terrificus (Viperidae) collected in the state of São Paulo (Motta, 1963a: 7-8).

Almeida \& Christoffersen (2002) emphasized that pentastomids are common parasites infesting the most different hosts found everywhere. In Northeast Brazil, only two pieces of work reported pentastomids on reptiles, Motta \& Gomes (1968) and Dias et al. (in press). The former authors described Raillietiella freitasi in the lungs of the Mabuya punctata lizards and Tropidurus torquatus, and in the Bufo paracnemis toad collected on the island of Fernando de Noronha, off the coast of the state of Rio Grande do Norte (administered by the government of the state of Pernambuco) and collected in the state of Bahia. Dias et al. (in press) recently reported the species Raillietiella aff. furcocerca parasitizing the lungs of Cnemidophorus abaetensis and Cnemidophorus ocellifer in the state of Bahia. The occurrence of C. tetrapoda as a parasite of snakes in northeastern Brazil has not yet been reported and the present work interrupts this forty year gap without any record of this group of animals in Brazil.

\section{MATERIAL AND METHODS}

Between January and August, 2004 we selected five collection sites: two in the Floresta Nacional do Araripe (FLONA) $\left(07^{\circ} 16^{\prime} \mathrm{S}\right.$ and $39^{\circ}$ $\left.26^{\prime} \mathrm{W}\right)$ and three on the banks of the Batateiras river, close to its source $\left(07^{\circ} 13^{\prime} \mathrm{S}\right.$ and $\left.39^{\circ} 38^{\prime} \mathrm{W}\right)$, which is located in the 'APA - Área de Proteção Ambiental' (a protected environmental area of the 'IBAMA - Institute for the Environment and
Natural Resources'), both in the municipality of Crato, state of Ceará, Northeast Brazil.

We captured the snakes by using the classical herpetological methods of pitfalls and the active patterned collection (Vanzolini \& Papavero, 1967; Auricchio \& Salomão, 2002). The municipality of Crato is situated in the south of Ceará, included in the bioregion of northeastern cariri, on the borders of the states of Ceará, Pernambuco, and Piauí. The Araripe consists of a patch of ecosystems as follows: i) Pluvio-nebular Tropical Subperennial Forest (a humid forest); ii) Pluvial Tropical Subdeciduous Forest (a dry forest); iii) Xeromorphic Tropical Subdeciduous Forest (the 'cerradão', a dense savannah-like vegetation); and iv) the Thorny Deciduous Forest (the 'caatinga', a typical northeastern vegetation with stunted trees and cactuses) (Campello et al., 2000). The herpetofauna is made up of species that are common to the Amazonian forest, Atlantic forest, and 'caatinga', and of endemic species (Rodrigues, 2003). The vegetation at our collection sites is part of the Humid Forest Complex, presenting a mean annual rainfall of $1,033 \mathrm{~mm}^{3}$ (Campello et al., 2000).

After collection, the snakes were fixed and preserved in $70 \%$ alcohol. They were subsequently identified according to Vanzolini et al. (1980).

The respiratory tract of the snakes was removed and the search for pentastomids was carried out under stereomicroscopy. Their identification was known according to the methods described by Rego (1983) and Riley (1986), by observing morphology of the body, the number of rings (of the superficial annulation of the body), the characteristics of the copulatory spicules of males, and dimensions of the hooks. There were not enough specimens for multiple measurements and statistical analysis.

\section{RESULTS}

Six specimens of Liophis lineatus were collected, two in the Floresta Nacional do Araripe and four in the APA. After the preservation treatment, they were housed in the collection of the Zoology Laboratory at the Universidade Regional do Cariri (LZ-URCA 0023, 0024, 0025, 0026, 0027, 0028). 
Among the six specimens of $L$. lineatus examined, only the one collected in the APA had its lungs infected by a male and a female of Cephalobaena tetrapoda (Figure 1, Table 1). We noticed that the pentastomids which had been collected were adults because of their simple hooks with no chitinous accessories, in opposition to nymphs, which have double hooks and chitinous accessories (Riley, 1986). The specimens of C. tetrapoda collected from the FLONA and the APA were preserved in recipients with $70 \%$ alcohol, labelled and housed in the collection at the Universidade Regional do Cariri, numbered as LZ-URCA 0043 and 0044.

This is actually, the first record of Cephalobaena tetrapoda as a parasite of snakes in Northeast Brazil, as well as the first record of a colubrid as a final host of this endoparasite in Brazil.

\section{Description}

- Cephalobaena tetrapoda Heymons, 1922;

- Syn: Raillietiella tetrapoda Sambon, 1922;

- Cephalobaena recurvocauda Motta, 1963;

- Site: lung;

- Hosts: Lachesis alternatus Duméril \& Bibron, 1854 (Viperidae) (Heymons, 1922); Crotalus terrificus Linnaeus, 1758 (Viperidae) (Motta 1963a); Liophis lineatus Linnaeus, 1758 (Colubridae) (in this work);

- Material: LZ-URCA 0043 e 0044;

- Female (Fig. 1b, c): body length/ thickness $34 \times 1.4$; abdomen with 38 annuli (part of abdomen is damaged); hooks simple, equal in size; cephalothorax trapezoidal (shaped like a "hand"), distinct from abdomen with rostrum long and large, and podial lobes long and retracted in sockets; mouth terminal; apical and dorsal papillae present and prominent; anus ventral; caudal papillae present; and
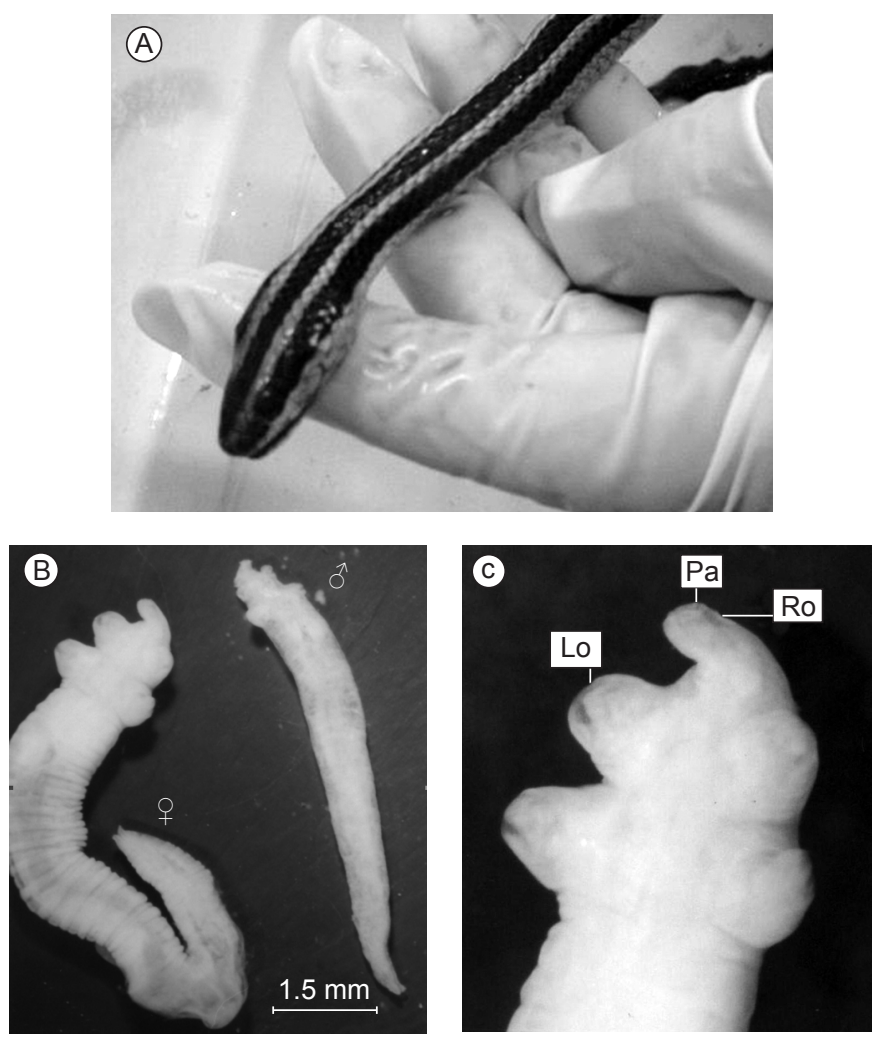

Fig. 1 - a) Liophis lineatus (LZ-URCA 0027) infected with; b) a female (LZ-URCA 0043) and a male (LZ-URCA 0044) of Cephalobaena tetrapoda viewed ventrally; c) cephalothorax (shaped like a "hand") of the female demonstrating some typical characters of species. Lo, podial lobe of the anterior hook; Pa, apical papillae; Ro, long rostrum. 
TABLE 1

Occurrence of Cephalobaena tetrapoda and dimensions and sex of specimens of Liophis lineatus collected in the Floresta Nacional do Araripe (FLONA) and in the 'APA - Área de Proteção Ambiental' (a protected environmental area of the IBAMA), in the state of Ceará.

\begin{tabular}{|c|c|c|c|}
\hline Specimens of $L$. lineatus & Sex & $\begin{array}{c}\text { Dimensions (rostrum-end } \\
\text { of tail, cm) }\end{array}$ & C. tetrapoda \\
\hline LZ-URCA 0023 & Female & 35 & - \\
\hline LZ-URCA 0024 & Female & 39 & - \\
\hline LZ-URCA 0025 & Female & 76 & - \\
\hline LZ-URCA 0026 & Female & 64 & - \\
\hline LZ-URCA 0027 & Male & 90 & + \\
\hline LZ-URCA 0028 & Female & 60 & - \\
\hline
\end{tabular}

- Male (Fig. 1b): body length/ thickness 14 x 0.8 of thickness; abdomen with indistinct annuli; hooks simple, equal in size, shaped like a claw; cephalothorax trapezoidal distinct from abdomen with rostrum and podial lobes large; mouth terminal; apical and dorsal papillae present and prominent; anus ventral; caudal papillae present.

\section{DISCUSSION}

Communities of parasites may affect the morphology of hosts, their external appearance, as well as reduce their fecundity and diet, influence on predator-prey dynamics and cause mortality (Marcogliese, 2004). Thus, the study of parasites is a priority, having the purpose of preserving biodiversity. Among these animals, the Pentastomida are poorly known, with respect to their biology and number of species in Northeast Brazil. The way these animals affect their host populations is also an unsolved mystery. Studies on pentastomids, despite having been emphasized as greatly needed by several authors (Self, 1969; Riley, 1986; Haugerud, 1989; Almeida \& Christoffersen, 2002), have not yet been published.

The present first record of Cephalobaena tetrapoda parasitizing Liophis lineatus will certainly be useful to understand the host-parasite relationships and their geographical distribution. In Brazil, this pentastomid had been related solely to large poisonous serpents (Motta, 1963a) (Table 2). However, our present result points to a broad form of C. tetrapoda utilizing hosts. L. lineatus, belonging to the family Colubridae, is quite a common snake in the caatinga and other ecosystems of the Brazilian semi-arid region. It has a diurnal habit, thriving on banks of rivers and lakes, as a batracophagous species (Vanzolini et al., 1980: 39), an aspect we confirmed here. Its habit of eating the young of toads and small toads (or 'caçotes', a Brazilian designation for small amphibians), makes L. lineatus popularly known in the cariri region of Ceará, as 'cobra-caçote' ('caçote'-snake). When examining the stomach content of individuals of this species, we observed they also feed on arthropods. On the other hand, adult viperids feed on a wide variety of adult and young vertebrates; and $L$. lineatus' young also feed on arthropods (Vanzolini et al., 1980: 64). We know that intermediate hosts of C. tetrapoda are still unknown (Riley, 1986: 47). However, we now suspect that small vertebrates, commonly found in their definitive hosts' diet, represent a potential intermediate host, an aspect that needs further investigation.

L. lineatus is geographically distributed from Paraguay, north of Argentina and Brazil to Panama (Vanzolini et al., 1980: 39). C. tetrapoda was formerly recorded as occurring in Uruguay, Paraguay, Argentina, and southeastern Brazil. Our results, however, showed that $C$. tetrapoda is widely distributed, extending to northern Brazil, overlapping with $L$. lineatus to some extent.

In conclusion, a certain amount of knowledge needed on pentastomids leads us to make a few enquiries concerning these animals as follows: i) which pentastomids species live in the North and Northeast regions of Brazil? ii) what impacts would they cause on their host populations? iii) should they maintain any intra- and interspecific 
TABLE 2

Pentastomids living as parasites on snakes of Brazil.

\begin{tabular}{|l|l|l|}
\hline \multicolumn{1}{|c|}{ Pentastomids } & \multicolumn{1}{|c|}{ Hosts } & \multicolumn{1}{c|}{ References } \\
\hline Cephalobaena tetrapoda & Crotalus terrificus, Liophis lineatus & Motta (1963a), Rego (1983); in this work \\
\hline Raillitiella furcocerca & $\begin{array}{l}\text { Boa constrictor, Coluber lichtensteinii, } \\
\text { Drymarchon corais, Crotalus terrificus, } \\
\text { Xenodon merremii, Lachesis sp. }\end{array}$ & Motta (1963b), Rego (1983) \\
\hline Kiricephalus coarctatus & $\begin{array}{l}\text { Dryadophis bifossatus, Aporophis lineatus, } \\
\text { Herpetodryas carinatus, Coluber corais }\end{array}$ & Sambon (1922b), Rego (1981) \\
\hline Porocephalus crotali & Crotalus terrificus & $\begin{array}{l}\text { Sambon (1922b), Heymons, (1935), } \\
\text { Rego (1981, 1984) }\end{array}$ \\
\hline
\end{tabular}

relationships with other communities of parasites? We look forward to answering these enquiries in the near future to help conserve our herpetofauna.

Acknowledgments - We are grateful to FUNCAP-Fundação Cearense de Apoio ao Desenvolvimento Científico e Tecnológico for our research grant (Ref. 943/03 - Edital 003/03), and the CNPq-Brazilian National Research Council for support from Samuel Vieira Brito's scholarship; to the IBAMA-Brazilian Institute for the Environment and Natural Resources for their permission to collect samples from reservation areas (080/04 - RAN/ IBAMA Processo 02007.001009/04-73); to Prof. Dr Davor Vrcibradic (UERJ), Prof. Dr Alexandre Vasconcellos (UFPB), and an anonymous reviewer for valuable suggestions and critics to the manuscript; to Prof. Antônio Álamo Feitosa Saraiva (URCA) for his help with our field work; and to Prof. Dr Breno Grisi for suggestions and the English version of the manuscript.

\section{REFERENCES}

ALI, J. H., RILEY, J. \& SELF, J. T., 1984a, A revision of the taxonomy of pentastomid parasites (genus Raillietiella Sambon, 1910) from American snakes and amphisbaenias. Syst. Parasitol., 6: 87-97.

ALI, J. H., RILEY, J. \& SELF, J. T., 1984b, Further observations of blunt-hooked raillietiellids (Pentastomida: Cephalobaenida) from lizards with descriptions of three new species. Syst. Parasitol., 6: 147-160.

ALI, J. H., RILEY, J. \& SELF, J. T., 1985, A review of the taxonomy and systematics of the pentastomids genus Raillietiella Sambon, 1910 with a description of a new species. Syst. Parasitol., 7: 111-123.

ALMEIDA, W. O. \& CHRISTOFFERSEN, M. L., 1999, A cladistic approach to relationships in Pentastomida. J. Parasitol., 85(4): 695-704.

ALMEIDA, W. O. \& CHRISTOFFERSEN, M. L., 2002, Pentastomida, pp. 187-202. In: J. Morrone \& J. Llorente-Bousquets (eds.), Biodiversidad, Taxonomía y Biogeografía de Artrópodos de México: Hacia una síntesis de su conocimiento, $3^{\circ}$ vol., 690p., Universidad Nacional Autónoma de México, México.
AURICCHIO, P. \& SALOMÃO, M. G., 2002, Técnicas de coleta e preparação de vertebrados para fins científicos e didáticos. Instituto Pau Brasil de História Natural, São Paulo, 348p.

CAMPELLO, F. C. B, LEAL-JÚNIOR, G., SILVA, J. A. \& CAMPELlO, R. C. B., 2000, Avaliação dos recursos florestais da Área de Proteção Ambiental Chapada do Araripe. Projeto MMA/FAO UTF/BRA/047, MMA Ministério do Meio Ambiente, Secretaria de Biodiversidade e Florestas, Diretoria do Programa Nacional de Florestas, Crato - CE, 49p.

DIAS, E. J. R., VRCIBRADIC, D., ROCHA, C. F. D., Endoparasites infecting two species of whiptail lizards (Cnemidophorus abaetensis and C. ocellifer; Teiidae) in a restinga habitat of northeastern Brazil. Herpetological Journal (in press).

HAUGERUD, R. E., 1989, Evolution in the pentatomids. Parasitol. Today, 5(4): 126-132.

HEYMONS, R., 1922, Beitrag zur Systematik und Morphologie der Zungenwümer (Pentastomida). Zool. Anz., 55: 154167.

HEYMONS, R., 1935, Pentastomida, pp. 1-267. In: H. G. Bronn (ed.), Klassen und Ordnungen der Tierreichs. Leipzig, Akademische Verlagsgesellschaft.

MARCOGLIESE, D. J., 2004, Parasites: small players with crucial roles in the ecological theater. Ecohealth, 1: 151164.

MOTTA, C. S., 1963a, Considerações sobre o gênero Cephalobaena Heymons, 1922 (Linguatulida), Cephalobaena tetrapoda. Atas Soc. Biol. Rio de Janeiro, 7(4): 7-8.

MOTTA, C. S., 1963b, Considerações sobre o gênero Raillitiella Sambon, 1910. Atas Soc. Biol. Rio de Janeiro, 7(2): 8-10.

MOTTA, C. S. \& GOMES, D. C., 1968, Sobre um novo gênero e uma nova espécie de Cephalobaenidae (Linguatulida, Cephalobaeniformia). Atas Soc. Biol. Rio de Janeiro, 12(1): 7-9.

REGO, A. A., 1981, Notas sobre alguns pentastomídeos de répteis. Mem. Inst. Butantan, 44/45: 233-238. 
REGO, A. A., 1983, Pentastomídeos de répteis do Brasil: Revisão dos Cephalobaenidae. Mem. Inst. Oswaldo Cruz, 78(4): 399-411.

REGO, A. A., 1984, Sinopse dos pentastomídeos da região neotropical. Garcia de Orta, Série Zoologia, Lisboa, 11: 45-46.

RILEY, J., 1986, The biology of pentastomids. Adv. Parasitol., 25: 45-128.

RODRIGUES, M. T., 2003, Herpetofauna da caatinga, pp. 181236. In: I. R. Leal, M. Tabarelli \& J. M. C. da Silva (eds), Ecologia e conservação da caatinga. Recife: Ed. Universitária da UFPE, 822p.

SAMBON, L. W., 1922a, A synopsis of the family Linguatulidae. J. Trop. Med. Hyg., 25: 391-428.
SAMBON, L. W., 1922b, A synopsis of the family Linguatulidae II. J. Trop. Med. Hyg., 25: 188-206.

SELF, J. T., 1969, Biological relationships of the Pentastomida; a bibliography of the Pentastomida. Exp. Parasitol., 24: 63119.

VANZOLINI, P. E. \& PAPAVERO, N., 1967, Manual de coleta e preparação de animais terrestres e de água doce. Departamento de Zoologia-USP, Secretaria da Agricultura do Estado de São Paulo, 223p.

VANZOLINI, P. E., RAMOS-COSTA, A. M. M. \& VITT, L. J., 1980, Répteis das caatingas. Academia Brasileira de Ciências, Rio de Janeiro, 161p. 